\title{
How do perceived CPA and political CSR interact in their relationships with citizens' trust in companies?
}

\author{
Authors: Vicent Tortosa-Edo and Miguel Ángel López-Navarro \\ Department of Business Administration and Marketing, Jaume I University, \\ Castelló de La Plana, Spain.
}

\begin{abstract}
:
Purpose - In the context of an industrial complex where corporate political activity (CPA) and political corporate social responsibility (political CSR) are not related, this study aims to investigate the possible relationship between citizens' perceptions of these two non-market strategies and residents' trust in companies located in the industrial complex.
\end{abstract}

Design/methodology/approach - Data were collected from 740 citizens living near a petrochemical complex in Tarragona (Spain). The results were analysed using structural equation modelling.

Findings - Based on institutional theory, the key findings of the study are that CPA and political CSR are differently related to citizens' trust in companies. The results also verify that the negative relationship (between CPA and trust) outweighs the positive one (between political CSR and trust).

Practical implications - The lack of fit between political CSR and CPA in the complex analysed suggests that firms are neglecting approaches shared by these non-market strategies, and thus wasting a huge opportunity to improve citizens' trust in and acceptance of the complex firms. Moreover, the ethical dimension should always be present when these firms take on political responsibilities.

Originality/value - To date, CPA and political CSR have largely been dealt with separately in the literature. This study attempted to bridge this gap by examining a situation where there is no strategic relationship between CPA and political CSR to analyse, from the perspective of citizens' perceptions, the relationship each strategy has with the important academic concept of citizens' trust in companies.

Keywords: Corporate political activity, Non-market strategy, Lobbying, Political corporate social responsibility, Trust in companies

\section{Paper type; Research paper}

This version of the paper has been accepted by Social Responsibility Journal. Emerald Publishing Limited, ISSN 1747-1117.

DOI: 10.1108/SRJ-09-2019-0294 


\section{How do perceived CPA and political CSR interact in their relationships with citizens' trust in companies?}

\section{Introduction}

Since the 1970s, firms have increasingly adopted a marked political role in their efforts to influence governments and public policy decisions (Vogel, 1983). This process has accelerated since the 1990s, with the rise of globalisation, and has been addressed in the academic literature through concepts such as corporate political activity (CPA) or political corporate social responsibility (political CSR). The first of these concepts, CPA, is concerned with the firm's policies, processes and practices that can be used to convey policy preferences to policymakers by providing information, making financial contributions, and constituency building (Hillman and Hitt, 1999). In turn, the concept of political CSR, which came out of the CSR literature, can be defined as corporate actions where companies turn into quasi-governmental actors - aimed at the provision of public goods and contribution to society (Ingenhoff and Marschlich, 2019). Actions that may also benefit the firm by enhancing its legitimacy (Baur and Schimtz, 2012).

Numerous contributions in the CPA (Banerjee and Benaik, 2018; Hillman and Hitt, 1999; Wöcke and Moodley, 2015) and political CSR (Bures, 2015; Joutsenvirta and Vaara, 2015) literatures are conceptually based on institutional theory (Meyer and Rowan, 1977). These authors argue that firms may undertake CPA or political CSR actions to adapt to and shape the regulative, normative and cultural-cognitive dimensions of their context (Scott, 1995, 2008), that is, of their institutional nonmarket environment (Banerjee, 2018). According to Baron (1995), CPA and political CSR can be considered as corporate nonmarket strategies. As such, firms may attempt to align their nonmarket strategies in order to improve their performance (den Hond et al., 2014). However, in practice many firms do not consider this possible strategic fit (Beloe 
et al., 2007; den Hond et al., 2014; Slob and Weyzig, 2009), a common situation in business contexts that has not been sufficiently explored in the literature. As a result, there is no empirical analysis on the possible consequences for corporate stakeholders of adopting CPA and political CSR actions simultaneously, but without relating them strategically. A further knowledge gap in this research area is the scarce attention to citizens and their opinions on this increasing corporate political role. Citizens are key stakeholders (Rehbein and Schuler, 2015), because political CSR actions such as the provision of public goods are designed for their benefit. They also bear the consequences of the political decision-making process that companies use to exert their influence through CPA actions such as lobbying. In consequence, neither the CPA nor the political CSR literatures have addressed a key element in the institutional research from the citizens' perspective, namely the public legitimacy or acceptance conferred on firms. Indeed, achieving greater corporate acceptance by increasing public trust in firms (Moffat and Zhang, 2014) has raised practical and academic concerns, especially in the context of potentially polluting firms and industrial complexes (López-Navarro et al., 2018). Finally, this study considers the principles of attribution (Kelley, 1967) and asymmetry (Slovic, 1993) in response to Aguinis and Glavas's (2012) call for more comprehensive academic analysis of the underlying mechanisms explaining the relationships proposed in the institutional-level research.

The aforementioned knowledge gaps are approached through two main research questions. First, how are citizens' perceptions of each nonmarket strategy (CPA and political CSR) related to their trust in the firms that implement these strategies? And second, which of these two relationships is quantitatively greater in absolute terms? Taking institutional theory as our conceptual basis, the study focuses on citizens living near an industrial complex, a context that meets all the conditions necessary to address 
the research questions posed.

The paper is structured as follows: in the next section we describe the scope of the study, in light of the specific characteristics of the case analysed. Then we present the theoretical background and the hypotheses of the model. The methodology is then explained, followed by the analysis of the results. The final section discusses the results and reports the main limitations and future research.

\section{Scope of the study}

The present study examines a petrochemical complex located to the south of Tarragona (Catalonia), on the Spanish Mediterranean coast. This complex covers an area of $7,200,000 \mathrm{~m}^{2}$, with 24 companies from the chemical sector, such as Dow Chemicals, BASF and Ercros. A second petrochemical complex is located to the north of Tarragona. Together the two complexes generate approximately 10,000 direct and over 30,000 induced jobs (around 60\% of which corresponds to the complex analysed in this study). The high concentration of chemical companies in Tarragona prompted the constitution in 1977 of the AEQT, a local industry association set up to represent companies from the sector located in the province.

We first analysed secondary information taken from corporate responsibility reports (published by the AEQT and the complex firms) and from news items about the complex in the local media. From this documentary review we conclude that the main firms analysed provide public goods with a clear social purpose, designed to improve the quality of life of local residents. Specifically, public goods related to education are a key aspect of the social responsibility actions implemented by most of the companies. A prime example of such action is their participation in what is known as dual vocational training. In this educational programme, students enrolled in the Industrial Chemistry 
higher-level training cycle study both at the Comte de Rius de Tarragona College and at the partner chemical firm. This public-private partnership is one of several educational initiatives undertaken by the major companies in the complex in collaboration with other public educational institutions. BASF, for example, has agreements and partnerships with universities such as the Universitat Rovira i Virgili (URV) in Tarragona, related to chemistry education and knowledge transfer. Through all these educational and training initiatives, citizens may perceive an intention by the firms to improve not only local students' skills and knowledge of chemistry but also the skills of their potential future employees.

In addition, some firms in the complex provide social care services for local citizens, although to a lesser extent than the educational initiatives. For instance, Ercros and Messer collaborate with local NGOs in social projects. They provide material or practical support through a voluntary employee scheme to improve the living conditions of local people affected by the drastic cuts to the public social services budget.

In contrast, lobbying functions are mainly carried out by the local industry association, AEQT, and concern issues listed on its website (https://www.aeqtonline.com/es/que-

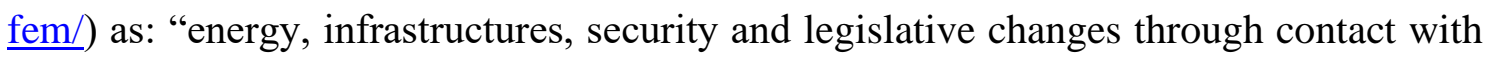
the legislative bodies and the main stakeholders in the area". This information shows that the association's main aim is to promote the chemical cluster (ChemMed) in conjunction with regional and local public authorities.

The AEQT also works alongside regional public authorities on environmental matters. A collaboration agreement was signed in 2005, and renewed in 2012, aiming to improve the regional public authority's mechanisms for evaluating and controlling environmental risks associated with the chemical firms, including those analysed in the present study. In fact, the main goal of this agreement is to support the application of 
the European Union industrial emissions directive (Directive 2010/75/EU of the European Parliament and the Council, 2010) in Tarragona's chemical industry. However, it should be noted that key stakeholders, such as neighbourhood associations or environmental NGO from the area, were not invited to participate in the discussions, formalisation and renewal of this agreement. In addition, the petrochemical industry's relationship with the regional public administration on environmental matters is not widely reported in the local media or in the firms' corporate responsibility reports. Such relative silence contrasts starkly with the firms' communication policy to publicise their provision of public goods in the area. In sum, the agreements on environmental issues negotiated with the public authorities by the AEQT on behalf of its members appear to result from the firms' strategic aspiration to influence public representatives' decisions on the evaluation and normative regulation of environmental risks deriving from their industrial activity.

Finally, the analysis uncovers a lack of strategic fit between the provision of public goods and lobbying functions. Following den Hond et al. (2014), the fact that corporations adopt two different nonmarket strategy actions that work on different and unrelated issues appears to explain the lack of strategic fit between them. Thus, in our research context, the individual firms in the complex provide public goods with an educational or social care function. In contrast, lobbying functions focus on the question of environmental regulation and are mainly undertaken through the AEQT on behalf of its members. In consequence, the lack of strategic fit in implementing CPA and political CSR actions explains why local residents may not perceive a relationship between these two nonmarket strategies. In light of the above, we consider that this industrial complex has all the necessary characteristics for the present study. The context enables us to analyse simultaneously the possible relationship between citizens' perceptions of each 
nonmarket strategy (CPA and political CSR) and citizens' opinions about the complex firms. Specifically, we evaluate levels of trust in the firms to reflect these citizen evaluations, as trust is a key factor in the public's acceptance of firms and the legitimacy conferred on them (Meyer and Rowan, 1977). In addition, the analysis of secondary information taken from corporate responsibility reports, published by the AEQT or the firms in the complex, corroborates the importance the firms place on raising levels of trust and acceptance in the local community, thereby creating a favourable impact on their institutional context.

\section{Theory and hypotheses}

\section{Theoretical background}

The provision of public goods and lobbying functions are well documented, respectively, in the academic fields of political CSR (Palazzo and Scherer, 2008; Scherer and Palazzo, 2011; Scherer et al., 2016) and CPA (Hillman et al., 2004; Tselengidis and Östergren, 2019). Specifically, the political CSR literature links corporate social responsibility (CSR) and political theory by arguing that CSR may be "political" when it focuses on a firm's assumption of governmental roles and responsibilities (den Hond et al., 2014). Hence, the concept of political CSR aims to redress the customary lack of analysis in the CSR literature of the political nature of actions such as corporate provision of public goods or firms' participation - in conjunction with other stakeholders - in governance initiatives (Scherer and Palazzo, 2011). Political CSR explicitly addresses social issues through discretionary corporate practices to advance community development, although these actions can also have favourable repercussions for the firms undertaking them (Ingenhoff and Marschlich, 2019).

On the other hand, firms may use information, financial incentives or constituency 
building to influence governmental policy or process (Getz, 1997). Specifically, the concept of CPA is applied to consider a number of actions and tactics such as lobbying, making campaign contributions, or conducting grassroots activities, among others, to influence public policy (Rehbein and Schuler, 2015). Firms may undertake lobbying functions, defined as the "provision of information to policy makers by individuals representing the firm's interests" (Hillman and Hitt 1999, p. 834). In the academic sphere, lobbying is generally seen as the key component in CPA (Anastasiadis, 2006; Marqués, 2017). Moreover, according to Coen (1997, p. 21) lobbying is the "best means of influencing" policy. Finally, traditional lobbying is carried out without citizen participation, and without any public awareness of the process firms follow to influence final outcomes, such as laws approved by public authorities. This lack of citizen involvement clearly differentiates lobbying from the inherent external approach of corporate provision of public goods.

Numerous contributions in both the political CSR and the CPA literatures (Albareda et al., 2007; Banerjee and Benaik, 2018; Bonardi et al., 2005; Bures, 2015; Luyckx and Janssens, 2016; Wöcke and Moodley, 2015) are conceptually grounded in institutional theory (Deephouse and Carter, 2005; Meyer and Rowan, 1977; Scott, 1995). Based on this theory, when firms implement nonmarket strategy actions, such as CPA or political CSR actions, they seek to adapt to and shape their institutional context (Ruef and Scott, 1998). In particular, they can affect the regulative, cultural-cognitive and normative elements of their social, cultural, and political contexts (Aguilera and Jackson, 2003; Scott, 1995), with the aim of maximising their legitimacy and increasing their survival capabilities (Meyer and Rowan, 1977).

In this vein, several studies hold that the purpose of adopting political CSR actions is to positively impact the public legitimacy or acceptance conferred on the firms that assume 
this political responsibility (Joutsenvirta and Vaara, 2015; Luyckx and Janssens, 2016). Indeed, political CSR actions such as the provision of public goods are specifically targeted at citizens. In order to gain acceptance, firms must win citizens' trust (Browne et al., 2011; Mercer-Mapstone et al., 2018). By acting in this way, firms aim to affect the normative and cultural-cognitive dimensions of their institutional environment (Scott, 1995). On the other hand, when firms implement CPA actions, their aim is to influence decisions taken by political representatives by gaining their acceptance and trust (Hillman, 2005; Liedong et al., 2015). In this way, firms seek to affect the regulative dimension of their institutional context (Scott, 1995). However, it is equally true that adopting CPA actions such as lobbying functions can also affect citizens' trust, as these are the stakeholders who bear the consequences of the political decisions taken, for example, on questions of legislation. It is citizens who uphold the cultural norms of conduct in society (Young and Makhija, 2014). Thus, implementing such CPA actions can affect the normative and cultural-cognitive dimensions of the institutional context (Scott, 1995).

Despite the political nature of both nonmarket strategies, empirical research has paid insufficient attention to the joint consideration of CPA and political CSR actions, and the consequences for stakeholders that can derive from their simultaneous application by corporations. The numerous contributions in the CPA and political CSR literatures based on institutional theory have not dealt with a central issue in this theoretical approach, namely citizens' trust in firms (Vlachos et al., 2009). In general, trust can be defined as "a psychological state comprising the intention to accept vulnerability based upon positive expectations of the intentions and behavior of another" (Rousseau et al., 1998, p. 395). In particular, trust is also an essential mechanism of policy influence (Liedong et al., 2015), and a key element to legitimate organisations (Meyer and 
Rowan, 1977).

The result of this failure to consider citizens' views is that, to date, the CPA and political CSR literatures have not analysed the underlying mechanisms which explain the sign and the magnitude of the relationship between citizens' trust and their perceptions of these two nonmarket strategies. The present study aims to bridge this knowledge gap by considering the principles of attribution (Kelley, 1967, 1972) and asymmetry (Slovic, 1993). Attribution theory is concerned with the way individuals evaluate the motives of others, and explains how these perceived motives influence their subsequent attitudes and behaviours. In particular, the motives citizens infer from or attribute to firms when they implement CPA or political CSR actions can help to explain the sign of the relationship between citizens' perceptions of the two nonmarket strategies and their trust in the firms. In turn, the asymmetry principle maintains that people attribute greater importance to negative information because of their extreme aversion to losses and costs (Kahneman and Tversky, 1984). The asymmetry principle can help to explain the greater magnitude, in absolute terms, of the negative sign that can arise between citizens' perceptions of the two nonmarket strategies and their trust.

\section{Hypotheses Development}

The lack of strategic fit between nonmarket strategies might explain why people perceive their signals separately (den Hond et al., 2014). Therefore, the relationship between the perceptions of political CSR and CPA actions and the public's trust in the

companies that undertake them depends on the separate evaluation of these two nonmarket strategies.

There are conflicting arguments about the possible relationship between CSR and trust in the general CSR literature. The debate hinges on whether companies carrying out CSR actions generate trust (Castaldo et al., 2009; Fatma et al., 2015) or, on the contrary, 
provoke mistrust or cynicism and suspicion (Porter and Kramer, 2004) among citizens who question the true motives behind these actions. In this vein, CSR has been harshly criticised as a manipulative "greenwashing" strategy (Brennan and Binney, 2008), or an undemocratic substitute for public policy because citizens do not vote for firms (Seidman, 2007).

The literature predominantly holds that a firm's CSR practices are positively related to consumers' attitudes to and beliefs about the corporation (Brown and Dacin, 1997; Park et al., 2014). However, some studies have followed the attribution approach to examine the circumstances under which CSR actions may not achieve that positive result (Kim and Lee, 2012; Sen and Bhattacharya, 2001; Zasuwa, 2019). In this line of study, Forehand and Grier (2003) demonstrated that when there is high congruence between the corporation and the social cause, this congruence leads to increased salience of organisation-serving motives, namely, the organisation's focus on economic gain and maximising profits. According to these authors, this situation has a negative impact on the public's evaluation of the corporation when the cause is expressed solely in terms of public-serving motives, which reflect concern for public welfare. However, the same negative impact on the public's evaluation does not occur when the firm acknowledges the existence of organisation-serving as well as public-serving motives (Kim and Lee, 2012; Terwel et al., 2009).

In the context of firms with potentially polluting activities, the risk research literature finds that such firms prioritise developing citizens' trust as a critical way of gaining broader societal acceptance (López-Navarro et al., 2013, 2018; Tortosa-Edo et al., 2014). This reasoning may explain why firms operating in controversial industries increasingly provide socially-oriented public goods such as educational and training services (Dougherty and Olsen, 2014; Frynas, 2009). Such services not only enhance 
education for local young people, but can also ensure a future pool of employees with appropriate technical skills for their industry. Similarly, some companies provide cultural or social care services for people living near their facilities, thus conveying the idea that they wish to improve the welfare or quality of life of the local community (Warhurst and Mitchell, 2000). These actions can also benefit the companies by increasing employees' job satisfaction (Bauman and Skitka, 2012) and organisational commitment (Brammer et al., 2007), since employees appreciate the considerable efforts firms make to benefit the community of which they and their families form part.

In performing this corporate political role, firms normally implement an active communication policy through their corporate responsibility reports or through press releases about their actions for the local and regional media. These measures are designed to raise public awareness of their initiatives and the motives behind them. People tend to trust a corporation when its CSR motive is communicated effectively (Kim and Lee, 2018).

Indeed, some studies on controversial industries have explored how CSR initiatives could mitigate stakeholders' usual defiance towards the firms that undertake these actions (Yoon et al., 2006), if they are perceived to be motivated by the aspiration to serve both the public and the organisation. In light of this literature and the results of empirical studies of the relationship between trust and CSR actions (Kim and Lee, 2012; Terwel et al., 2009), we suggest that the firms' active communication policies generate the perception among citizens living near the industrial complex that they are providing public goods such as education or social care services which benefit the community. In addition, these corporations are serving the interests of the industry itself, thereby demonstrating their honest motivations. This perception may be favourably related to citizens' trust in these firms. Based on this argument we propose our first research 
hypothesis:

$H_{1}$ : The perception held by citizens of corporations' provision of socially-oriented public goods, to which they attribute public-serving and organisation-serving motives, is positively related to their trust in these corporations.

As regards lobbying, there is increasing concern that firms are crossing the line between legitimate participation in democratic decision making and the opportunistic pursuit of self-interest (den Hond et al., 2014). In liberal democracies firms have a wellestablished right to participate in the political system (Anastasiadis, 2006). Lobbying must therefore be considered as wholly legitimate in ensuring balanced policy making (Grimaldi, 1998), and in achieving the most socially beneficial outcomes possible (Anastasiadis, 2014). Corporations can enhance the decision-making process by contributing with their experience and knowledge to improve evaluation, regulation and monitoring in spheres in which they are involved as stakeholders (Grant, 2000). Indeed, several authors contend that firms can contribute to the social good through lobbying (Peterson and Pfitzer, 2009; Rasche, 2015).

In contrast, other authors argue that corporations may use lobbying to influence governments unduly (Doh et al., 2012; Lawton et al., 2013). Companies may try to impose their own interests on public authorities in developing regulation and control in specific areas that affect them (Nyberg et al., 2013). Negative public opinion about traditional corporate lobbying may be explained by the perception that it is not designed to resolve public issues (Barley, 2007; Lock and Seele, 2016). This citizen perception may be strengthened by the traditionally "covert rather than overt" (Harris and Lock, 1996, p. 320) nature of the way it is carried out (Lyon et al., 2018). The absence of citizen participation, together with the dearth of information on the scope and objectives 
of firms' lobbying actions, can reinforce citizens' beliefs that this nonmarket strategy is undertaken solely for self-interested reasons. Citizens may perceive that this CPA action is designed to exclusively benefit the corporations themselves (Lock and Seele, 2016). Following the attribution approach, people may only infer organisation-serving motives (Terwel et al., 2009) from these lobbying functions.

In the context of potentially polluting industrial sectors, companies are generally regarded as self-interested (Gamero et al., 2011). Moreover, public authorities are seen as being heavily influenced by these firms in their evaluations and decisions related to environmental costs and risks (Espluga et al., 2010; Gamero et al., 2011). In fact, although lobbying by individual firms does take place, they may choose to carry out this function through the industrial associations that represent them. The reason for this decision could be related to the need to avoid any relationship with lobbying functions due to the negative public perception of this political role (den Hond et al., 2014; Marqués, 2017). We consider that citizens living near the analysed complex may have less trust in companies when they lobby on issues of environmental costs and risks, mainly through their industry association, in the traditional covert way. Citizens may perceive that corporations are only interested in what benefits them, and that they are imposing disproportionate costs on the rest of society (Faccio, 2010). This leads us to our second hypothesis:

$\mathrm{H}_{2}$ : The perception held by citizens of corporate lobbying of public authorities on environmental issues, to which they attribute organisation-serving motives, is negatively related to their trust in these corporations.

Finally, the combined evaluation of the relationship between the two nonmarket strategies and citizens' trust in companies is an important issue that has not been 
addressed in the literature, especially from a quantitative perspective. The industrial complex in our study is a clear example of lack of strategic fit between CPA and political CSR. For this reason, this context can be used to make a quantitative comparison of the relationships proposed between the public's perception of the two nonmarket strategy actions and their trust in companies. Trust is widely believed to be a fragile concept (Eitzinger and Wiedemann, 2008), since it can be instantly destroyed by a small mistake (Kasperson et al., 1992). In this line, Slovic (1993) applies the asymmetry principle to argue that perceived negative events erode trust to a much greater extent than positive ones increase it. This principle has been tested in several studies (Eitzinger and Wiedemann, 2008; Poortinga and Pidgeon, 2004), some of which analyse polluting industries (Cvetkovich et al., 2002; Siegrist and Cvetkovich, 2001). In this vein, and in relation to the petrochemical industry, López-Navarro et al. (2016) confirm that the local community prioritises environmental issues over economic ones in their behavioural intentions. They endorse the argument that the damage of a loss (environmental costs) tends to outweigh the benefits (economic consequences).

Based on the above, in the present study context we consider that what is assumed to be a negative relationship between perceived lobbying functions and trust in companies will be greater than the hypothesised positive relationship between the perception of the provision of public goods and this trust. We therefore propose our final hypothesis:

$H_{3}$ : The negative relationship between the citizens' perception of corporate lobbying of public authorities on environmental issues and their trust in these corporations outweighs the positive relationship between the citizens' perception of the provision of socially-oriented public goods and their trust in these corporations. 


\section{Methodology}

\section{Data collection, sample and analytical procedure}

The fieldwork for this research was carried out by means of personal street interviews with citizens who lived close to the complex. The final questionnaire consisted of closed questions with items measured on a five-point Likert scale (1, lowest agreement, 5, highest agreement). A total of 740 valid responses were obtained using simple random sampling. According to the Spanish Institute of Statistics (2011), the total population of the localities surveyed near the complex on the south side of Tarragona was 74,651 , which for a $95 \%$ confidence level represents a sample error of $\pm 3.74 \%$ $(p=q=0.5)$. Of the total responses, $397(53.6 \%)$ were from women and $343(46.4 \%)$ from men. Most of the responses, 286, were from people between the ages of 26 and 45, (38.7\%), followed by 216 citizens aged between 46 and $65(29.4 \%)$ and 149 respondents over the age of $65(20.1 \%)$; the youngest group comprised 89 people $(12 \%)$ aged between 18 and 25 .

The model was empirically validated using structural equation modelling (SEM), through the EQS 6.2 statistical software package, with the maximum likelihood estimation method. The modelling consists of two stages. First, a confirmatory factor analysis tests whether the measured variables can be used as indicators for the model factors. The second part of SEM is commonly known as the structural model, and is concerned mainly with the relationships between the latent variables.

\section{Measures}

The items representing the model variables were adapted from previous studies or designed specifically for this study. Thus, to represent citizens' perception of corporate provision of public goods aimed at improving quality of life in the community, we used 
the item: "the companies in the industrial estate invest some of their profits in improving the quality of life of the community" (P.1.1). Clarification was provided with examples of investments by local firms such as "educational services, cultural services, etc". The item representing citizens' perception of corporate lobbying of public authorities in evaluating environmental risks was "public authorities are heavily influenced by the companies in the industrial estate when evaluating environmental risks" (P.2.1). By including the expression "heavily influenced" in the item, we aimed to assess whether citizens really perceive that these firms have a notable influence, through high levels of lobbying activity, on public authority decisions about environmental issues. Finally, the scale representing trust in companies was measured by five items (see Table 1) from the work of ter Huurne and Gutteling (2009).

We used single-item measures to represent citizens' perceptions of corporate provision of public goods and of corporate lobbying of public authorities, as the object and the attribute to be represented in both cases can be conceptualised as concrete and singular (Bergkvist and Rossiter, 2007; Drolet and Morrison, 2001). In the present study the local citizens perceive the industrial complex as a specific, single unit (the firms in the complex are all perceived as the same subject) and do not distinguish the benefits and costs that might be associated with each individual firm located there. Similar perceptions have been found in other industrial complexes analysed in the literature (Phillimore and Moffat, 2004; Signorino, 2012). In addition, we focus on citizens' perceptions of two concrete nonmarket strategy actions; provision of public goods to improve well-being in the community and lobbying of public authorities on how environmental risk is evaluated. Furthermore, previous research comparing the predictive validity of single-item measures versus multiple-item measures of the same concrete and singular constructs show that the single-item measures are equally 
effective (Bauer, 2016). Following these arguments, numerous empirical studies have used single-item measures to represent different constructs such as CSR importance (Du et al., 2015); purchase behaviour or intention (Lacey and Kennett-Hensel, 2010; Sen and Bhattacharya, 2001; Zasuwa, 2019); customer satisfaction (Rust et al., 1995); or need for information (Tortosa-Edo et al., 2016). For all these reasons, we consider that single-item measures are appropriate to represent the two constructs reflecting perceptions of lobbying functions and public goods.

\section{Common Method Variance}

Finally, every effort was made in the research design and the data analysis to prevent and assess the effect of common method variance. In the research design stage, we informed all the participants that their anonymity and the confidentiality of their responses would be guaranteed (Mackenzie and Podsakoff, 2012). Additionally, in the survey we separated the questions on the independent variables from those on the dependent variables (Podsakoff and Organ, 1986), as the questionnaire covered other variables not related to those considered for this article. Furthermore, in order to explore the degree of common method variance (CMV) in the data, we followed Podsakoff et al.'s (2003) approach to consider a marker variable in our study. The marker variable used was a one-item scale to measure whether neighbourhood relations were friendly in the area, because this concept is theoretically unrelated to at least one variable in the study (Malhotra et al., 2006).

\section{Results of the empirical study}

Several analyses were conducted to ensure that all the criteria met the desired characteristics of dimensionality, reliability and construct validity. These analyses were not performed on provision of public goods or corporate lobbying, both of which were 
represented by a single item and were considered as observable variables (Table 1).

In the confirmatory factor analysis, the Lagrange multiplier test revealed two necessary modifications to improve the fit indices. These were the error correlations between the items P.3.1-P.3.4 and P.3.2-P.3.5, with similar content for the citizens in the sample. The final measurement model showed an acceptable fit (Satorra-Bentler $X^{2}=57.162$; df $=11 ;$ p-value $<0.05 ; \mathrm{BBNFI}=0.989 ; \mathrm{CFI}=0.991 ; \mathrm{RMSEA}=0.075)$, with the ratio $\left(X^{2} / \mathrm{df}\right)$ slightly above 5 , but with the remaining indices above or below the recommended cut-off values. The factor loadings were higher than 0.7 and the t-test was significant for all items of the latent variables (Table 1). Composite reliability was used to assess the reliability of these scales, all of which were above the 0.7 threshold.

\section{Insert table 1 about here}

Convergent validity was assessed using the Bentler-Bonett normed fit index (BBNFI), which yielded a value greater than 0.9 . This value confirms convergent validity (Table 1). In addition to this analysis, the average variance explained (AVE) of the latent variable of the model was higher than the recommended minimum value of 0.5 .

Finally, discriminant validity was also supported, since the square root of the average variance extracted $\left(\mathrm{AVE}^{1 / 2}\right)$ of the latent variable was higher than the correlations between this variable and the other two factors (Table 2).

Insert table 2 about here

Table 2 shows that there is no significant correlation between the two variables representing citizens' perceptions of political roles undertaken by firms in the complex. As expected, the citizens surveyed also perceived the lack of strategic fit between lobbying functions and the provision of public goods.

Common method variance was not a major threat as the marker variable correlated on 
average with the other latent constructs at less than $r=0.08$ (Hashim et al., 2018), and the pattern and magnitude of correlations did not change significantly before and after the marker variable was included in the measurement model (Katsikeas et al., 2018).

In the second stage of SEM, we estimated the structural model (Table 3). Several statistics corroborated an acceptable fit of the model (Satorra-Bentler $X^{2}=60.364$; $\mathrm{df}=$ 12; -value $<0.05 ; \mathrm{CFI}=0.991 ; \mathrm{BBNFI}=0.989 ; \mathrm{RMSEA}=0.074)$, with the ratio $\left(X^{2} / \mathrm{df}\right)$ very slightly above 5 , but again with the remaining indices above or below the recommended cut-off values.

Insert table 3 about here

The analysis of the results corroborated all the hypotheses. Firstly, they verified that citizens' perception of corporate provision of public goods is positively related to their trust in the firms $\left(0.302 ; \mathrm{H}_{1}\right)$. Likewise, citizens' perceptions of corporate lobbying is negatively related to their trust in the firms $\left(-0.348 ; \mathrm{H}_{2}\right)$. Finally, in absolute terms the relationship between the citizens' perception of corporate lobbying functions and their trust in the complex firms is greater than that between their perception of corporate provision of public goods and this trust $\left(\mathrm{H}_{3}\right)$.

\section{Discussion}

\section{Theoretical contribution}

The current predominantly neoliberal context seems to explain why stakeholders' expectations of the public and private sectors are converging. The public sector is expected to incorporate market-oriented thinking, and the private sector is expected to become more socially and politically responsible (Timonen and Luoma-aho, 2010).

The response in the literature to companies' increasing political role is seen in the 
academic field that applies concepts such as CPA and political CSR. Several contributions (Banerjee and Benaik, 2018; Bures, 2015; Hillman and Hitt, 1999; Joutsenvirta and Vaara, 2015), based on institutional theory (Meyer and Rowan, 1977), hold that by undertaking CPA or political CSR actions, firms aim to influence the social, political and legal environment. However, to date these two nonmarket strategies have largely been dealt with separately in the literature. This individual analysis has precluded any investigation into a possible relationship between them, and the main consequences they may have, either jointly or separately.

The present study has attempted to bridge this knowledge gap in the literature by examining a real situation that is found in numerous business contexts (Beloe et al., 2007; den Hond et al., 2014), namely, when firms implement CPA and political CSR actions simultaneously and do not consider the possible strategic fit between them. This reality offers an interesting area of study as well as an appropriate situation for analysing and comparing the relationship each of these two nonmarket strategies may have, independently, with relevant concepts related to corporate stakeholders. In this vein, the present study also contributes to the literature in that it focuses on the external sphere of the organisation by considering citizens. In fact, the failure to consider such key stakeholders (Rehbein and Schuler, 2015) explains why neither the CPA nor the political CSR literatures have addressed a key aspect in institutional theory, namely the public's acceptance or legitimisation of companies. Public trust is crucial to gaining this acceptance (Browne et al., 2011; Moffat and Zhang, 2014). Indeed, citizen trust has aroused great practical and academic interest, particularly in contexts where environmental risks are associated with industrial activity (López-Navarro et al., 2018; Owen and Kemp, 2013). In addition, the empirical nature of the study allowed us to consider the underlying mechanisms, by means of the attribution and asymmetry 
principles, which explain the sign and magnitude of the relationships between citizens' perceptions of each nonmarket strategy and their trust in the firms that apply them, thereby contributing to the institutional-level research (Aguinis and Glavas, 2012). Finally, the present study therefore responds to calls in the literature for more empirical research into aspects of the relationship between business and society (Oll et al., 2018).

Two main findings arise from the empirical analysis of this industrial context:

First, citizens' perceptions of the public goods provided by firms in the complex are related to their greater trust in firms. Citizens attribute social concern and interest to these corporate actions. They perceive a public-serving (altruistic or other-centred) motivation as well as an organisation-serving (egoistic or self-centred) motivation (Kim and Lee, 2012; Terwel et al., 2009; Yoon et al., 2006). By actively publicising their investments in society, firms in the complex signal to their stakeholders their intentions to establish good relations with their nonmarket environment (Rehbein and Schuler, 1999). At the same time, these firms are signalling a desire to enhance the technical skills and knowledge of future employees in the complex (by providing education) or to increase current employees' satisfaction and commitment (by offering social care services). This finding contrasts with the study by Brammer and Millington (2005), where the absence of any public perception of a clear organisation-serving motivation for the firms' CSR actions (philanthropy) did not appear to operate positively in environmentally sensitive industries. On the other hand, citizens' perceptions of corporate lobbying are negatively related to trust in the firms. This relationship may be explained by citizens' perception that the firms (represented by the AEQT) are not motivated by a desire to resolve public issues. Citizens infer that firms try to avoid stepping up prevention measures to reduce the environmental impact of their industrial activity. This negative attribution appears to have intensified as a result of the procedure 
adopted by the AEQT to prepare the collaboration agreements aimed to improve the regional public authority's mechanisms for evaluating and controlling environmental risks. Specifically, key stakeholders such as neighbourhood associations or local environmental NGOs were not invited to participate in these agreements. Moreover, the negotiation process was not reported in the local press or on the websites of the AEQT or the firms it represents.

Second, and in our opinion the main contribution to the literature, is the empirical verification that the positive relationship between citizens' perceptions of a political CSR strategy (offering public goods), and citizens' trust in those firms is completely outweighed in absolute terms by the negative relationship between citizens' perceptions of a CPA strategy (lobbying functions) and citizens' trust in them. By implementing this CPA action the firms aim to influence the regulatory dimension of the institutional context (Scott, 1995), but this appears to have a negative impact on the normative and cultural-cognitive dimensions upheld by local citizens. The results of this study therefore confirm the asymmetry concept defended by Slovic (1993).

\section{Practical implications}

The present study also has managerial implications for the analysed complex. One implication is related to the lack of strategic fit between political CSR and CPA actions. This situation suggests that firms and the AEQT are neglecting approaches shared by these nonmarket strategies, which represents a huge wasted opportunity to deliver greater value to themselves and to society (Beloe et al., 2007). On the understanding that the firms in this study wish to improve citizens' welfare through the provision of public goods, the research seems to confirm the practical need for the companies analysed to complement lobbying functions, either individually or collectively, with 
political CSR objectives and issues. Such a change could ensure that synergies between them would emerge and be perceived (den Hond et al., 2014). This complementarity therefore suggests the advisability not only of introducing more similar communication policies for both nonmarket strategy actions but also of seeking common issues and objectives for them. It is also important not to leave out the ethical dimension whenever the AEQT and the firms it represents take on political responsibilities.

In this line, we consider that the complex firms could improve public trust in them by adopting an alternative CPA strategy model, known as deliberative lobbying (Lock and Seele, 2016). This alternative departs from the most traditional and instrumental corporate lobbying style of "covert rather than overt" (Harris and Lock, 1996, p. 320). Deliberative lobbying is based on the normative idea of deliberative democracy (Habermas, 1996), in which all voices are heard when consensual decisions are reached through inclusive and transparent participatory processes. In this way, the opinions of stakeholders (local residents, for example) are taken into account when the complex firm managers, who also form part of the AEQT management, take decisions on the nature and scope of their CPA actions. Indeed, this change in the undertaking of lobbying functions might, in our view, tackle the real root of the problem. Following Grimaldi (1998, p. 247), the problem arises "when the players engaged in the democratic process use it as an arena for self-interested action unrestrained by ethical considerations". Yet the AEQT, and firms in the complex, should adopt the ethical dimension - for example, considering their results in terms of the common good - when undertaking lobbying functions rather than exclusively serving their own interests. In his discussion of nonmarket strategy, Baron (2013) argues that the ethical dimension must be present in both the academic sphere of the concept and in its business practice. However, the reality is that ethics should be considered by CPA researchers as well as 
practitioners (Mantere et al., 2006).

As regards the public administrations in the area, we consider that they should avoid any partisan influence from stakeholders. For example, they should resist any influence from complex firms when regulating socially important issues such as the evaluation and control of industrial environmental pollution. In our view, if the local public administrations aspire to improveing the way they adapt to the demands of a key stakeholder in their context, namely citizens, they must commit to a process of participative democracy (Davidson, 2017) entailing more transparent decision making and greater citizen participation. Two possible instruments that may be considered for this purpose are popular legislative initiatives and citizen consultations on questions of great social importance such as industrial pollution.

Finally, we consider that the practical implications and academic interest of these results extend beyond the real case analysed in this study. Corporations have been assuming an increasingly widespread political role since the end of the last century. This phenomenon is particularly prominent among potentially polluting firms and industrial complexes (Frynas, 2009), where nonmarket strategies such as the provision of public goods or lobbying functions tend to be implemented simultaneously, but are not always related. The purpose of assuming such corporate social responsibilities is to gain the trust, and by extension, the acceptance of key stakeholders such as residents in the locality of these firms or complexes (López-Navarro et al., 2018; Moffat and Zhang, 2014). Apart from this particular industrial situation, we believe that the present study will be of interest to any type of company, in both developed and developing countries, that undertakes CPA or political CSR actions with the aim of building greater trust and acceptance in its nonmarket environment. 


\section{Limitations and future research}

As in other empirical studies, our findings have limitations and should be interpreted with caution. First, the model was developed and tested using the same dataset. It should be applied in different residential areas near other petrochemical complexes or in different industrial activities to validate our results and to assess the model's generalisability to other contexts. We also used perceptual data to measure the variables of the model and it should be acknowledged that the perceptions of those surveyed might not provide an accurate view of reality. Furthermore, the study did not consider any construct to represent the motives citizens attribute to firms when they are perceived to be implementing nonmarket strategies. Finally, this was not a longitudinal study and therefore it cannot establish the direction of causality between the study variables. Specifically, we do not know whether citizens' perceptions of corporations' nonmarket strategies are antecedents of their trust in the firms or, following the causal model of trust (Eiser et al., 2002), whether their trust in the firms influences the perceptions they have of the two nonmarket strategy actions.

Future research should study questions such as how firms coordinate collective actions via business associations, or the different roles and levels of involvement individual firms have in them. It would also be of interest to include political CSR-type actions in the model, in addition to public goods provision, or other actions to represent a CPA construct as well as lobbying functions. All these proposals are in the interest of furthering analysis on how such strategies are able to impact regulative, normative and cultural-cognitive elements in the surrounding context. Finally, a further line of research might analyse the growing political role of companies and business associations at the macro level (state or supranational) related, for example, to a vital issue at the beginning of this new millennium: climate change. 


\section{References}

Aguilera, R.V. and Jackson, G. (2003). "The cross-national diversity of corporate governance: Dimensions and determinants", Academy of Management Review, Vol. 28 No. 3, pp. 447-465.

Aguinis, H. and Glavas, A. (2012). "What we know and don't know about corporate social responsibility: A review and research agenda", Journal of Management, Vol. 38 No. 4, pp. 932-968.

Albareda, L., Lozano, J.M. and Ysa, T. (2007). "Public policies on corporate social responsibility: The role of governments in Europe", Journal of Business Ethics, Vol. 74 No. 4, pp. 391-407.

Anastasiadis, S. (2006). "Understanding corporate lobbying on its own terms", CCSR research paper serie, No. 42, International Centre for Corporate Social Responsibility, Nottingham, UK.

Anastasiadis, S. (2014). "Toward a view of citizenship and lobbying: Corporate engagement in the political process", Business \& Society, Vol. 53 No. 2, pp. 260-299.

Banerjee, S.B. (2018). "Transnational power and translocal governance: The politics of corporate responsibility", Human Relations, Vol. 71 No. 6, pp. 796-821.

Banerjee, S. and Venaik, S. (2018). "The effect of corporate political activity on MNC subsidiary legitimacy: An institutional perspective", Management International Review, Vol. 58 No. 5, pp. 813-844.

Barley, S.R. (2007). "Corporations, democracy, and the public good", Journal of Management Inquiry, Vol. 16 No. 3, pp. 201-215.

Baron. D. (1995). "Integrated strategy: Market and nonmarket components", California Management Review, Vol. 37 No. 3, pp. 47-65. 
Baron, D.P. (2013). Business and its Environment, Pearson, Upper Saddle River, NJ.

Bauer, T. (2016). Responsible lobbying: An empirical study in the EU. Annals in Social Responsibility, Vol. 2 No. 1, pp. 63-82.

Bauman, C.W. and Skitka, L.J. (2012). “Corporate social responsibility as a source of employee satisfaction", Research in Organizational Behavior, Vol. 32, pp. 63-86.

Baur, D. and Schmitz, H.P. (2012). "Corporations and NGOs: When accountability leads to co-optation”, Journal of Business Ethics, Vol. 106 No.1, pp. 9-21.

Beloe, S., Harrison, J.and Greenfield, O. (2007). Coming in from the Cold. Public Affairs and Corporate Responsibility, SustainAbility, London, UK.

Bergkvist, L. and Rossiter, J.R. (2007). "The predictive validity of multiple-item versus single-item measures of the same construct", Journal of Marketing Research, Vol. 44 No. 2, pp. 175-184.

Bonardi, J-P., Hillman, A.J. and Keim, G.D. (2005). "The attrativeness of political markets: Implications for firm strategy", Academy of Management Review, Vol. 30 No. 2, pp. 397-413.

Brammer, S. and Millington, A. (2005). "Corporate reputation and philanthropy: An empirical analysis”, Journal of Business Research, Vol. 61 No. 1, pp. 29-44.

Brammer, S., Millington, A. and Rayton, B. (2007). "The contribution of corporate social responsibility to organizational commitment", The International Journal of Human Resource Management, Vol. 18 No. 10, pp. 1701-1719.

Brennan, L. and Binney, W. (2008). "Is it green marketing, greenwash or hogwash? We need to know if we want to change things", in Jones, S. (Ed.), Partnerships, Proof and 
Practice - International Nonprofit and Social Marketing Conference, University of Wollongong, Wollongong, AU.

Brown, T.J. and Dacin, P.A. (1997). "The company and the product: Corporate associations and consumer product responses", Journal of Marketing, Vol. 61 No. 1, pp. $68-84$.

Browne, A.L., Stehlik, D. and Buckley, A. (2011). "Social licences to operate: for better not for worse; for richer not for poorer? The impacts of unplanned mining closure for “fence line" residential communities", Local environment, Vol 16 No. 7, pp. 707-725.

Bures, O. (2015). "Political corporate social responsibility: Including high politics?", Journal of Business Ethics, Vol. 129 No. 3, pp. 689-703.

Castaldo, S., Perrini, F., Misani, N. and Tencati, A. (2009). "The missing link between corporate social responsibility and consumer trust: The case of fair trade products", Journal of Business Ethics, Vol. 84 No. 1, pp. 1-15.

Coen, D. (1997). “The European business lobby”, Business Strategy Review, Vol. 8 No. 4, pp. 17-25.

Cvetkovich, G., Siegrist, M., Murray, R. and Tragesser, S. (2002). "New information and social trust: Asymmetry and perseverance of attributions about hazard managers", Risk Analysis, Vol. 22 No. 2, pp. 359-367.

Davidson, N. (2017). "Crisis neoliberalims and regimes of permanent exception", Critical Sociology, Vol. 43 No. 4-5, pp. 615-634.

Den Hond, F., Rehbein, K.A., de Bakker, F.G.A. and Kooijmans-van Lankveld, H. (2014). "Playing on two chessboards: Reputation effects between corporate social 
responsibility (CSR) and corporate political activity (CPA)", Journal of Management Studies, Vol. 51 No. 5, pp. 790-813.

Deephouse, D.L and Carter, S.M. (2005). "An examination of differences between organizational legitimacy and organizational reputation", Journal of Management Studies, Vol. 42 No. 2, pp. 329-360

Directive 2010/75/UE of the European Parliament and the Council. (2010). "Eurlex. Europa”, available at:

http://eurlex.europa.eu/legalcontent/EN/TXT/PDF/?uri=CELEX:32010L0075\&from=EN, (accessed 1 July 2016).

Doh, J.P., Lawton, Th.C. and Rajwani, T. (2012). “Advancing nonmarket strategy research: Institutional perspectives in a changing world", Academy Management Perspectives, Vol. 26 No. 3, pp. 22-39.

Dougherty, M.L. and Olsen, T.D. (2014). “Taking terrain literally: Grounding local adaptation to corporate social responsibility in the extractive industries", Journal of Business Ethics, Vol. 119 No. 3, pp. 423-434.

Drolet, A.L. and Morrison, D.G. (2001). "Do we really need multiple-item measures in service research?”, Journal of Service Research, Vol. 3 No. 3, pp. 196-204.

Du, S., Bhattacharya, C. B. and Sen, S. (2015). "Corporate social responsibility, multifaceted job-products, and employee outcomes", Journal of Business Ethics, Vol. 131 No. 2, pp. 319-335.

Eiser, J.R., Miles, S. and Frewer, L.J. (2002). “Trust, perceived risk and attitudes towards food technologies", Journal of Applied Social Psychology, Vol. 32 No. 11, pp. 2423-2433. 
Eitzinger, C. and Wiedemann, P.M. (2008). "Trust in the safety of tourist destinations: Hard to gain, easy to lose? New insights on the asymmetry principle”, Risk Analysis, Vol. 28 No. 4, pp. 843-853.

Espluga, J., Prades, A. and Gonzalo, J. (2010). "Communicating at the edge: Risk communication processes and structural conflicts in highly industrialized petrochemical areas”, Catalan Journal of Communication \& Cultural Studies, Vol. 2 No. 2, pp. 231251.

Faccio, M. (2010). “Differences between politically connected and nonconnected firms: A cross-cultural analysis", Financial Management, Vol. 39 No. 3, pp. 905-928.

Fatma, M., Rahman, Z. and Khan, I. (2015). "Building company reputation and brand equity through CSR: the mediating role of trust", International Journal of Bank Marketing, Vol. 33 No. 6, pp. 840-856.

Forehand, M.R. and Grier, S. (2003). "When honesty is the best policy? The effect of stated company intent on consumer scepticism”, Journal of Consumer Psychology, Vol. 13, pp. 349-356.

Frynas, J.G. (2009). "Corporate social responsibility in the oil and gas sector", Journal of World Energy Law and Business, Vol. 2 No. 3, pp. 178-195.

Gamero, N., Espluga, J., Prades, A., Oltra, Ch., Solá, R. and Farré, J. (2011). "Institutional dimensions underlying public trust in information on technological risk", Journal of Risk Research, Vol. 14 No. 6, pp. 685-702.

Getz, K.A. (1997). "Research in corporate political action: Integration and assessment", Business \& Society, Vol. 36 No. 1, pp. 32-72. 
Grant, W. (2000). Pressure Groups and British Politics, Macmillan, Basingstoke, UK.

Grimaldi, J. (1998). "Ethical business around the world: Ethics and the political activities of US business", Business Ethics: A European Review, Vol. 7 No. 4, pp. 245249.

Habermas, J. (1996). Between Facts and Norms: Contributions to a Discourse Theory of Law and Democracy, MIT Press, Cambridge, MA.

Harris, Ph. and Lock, A. (1996). "Machiavellian marketing: The development of corporate lobbying in the UK", Journal of Marketing Management, Vol. 12 No. 4, pp. 313-328.

Hashim, M.J., Kannan, K.N. and Wegener, D.T. (2018). "Central role of moral obligations in determining intentions to engage in digital piracy", Journal of Management Information System, Vol. 35 No. 3, pp. 934-963.

Hillman, A.J. (2005). Politicians on the board of directors: Do connections affect the bottom line? Journal of Management, Vol. 31, pp. 464-481.

Hillman, A.J. and Hitt, M.A. (1999). “Corporate political strategy formulation: A model of approach, participation, and strategy decisions", Academy of Management Review, Vol. 24 No. 4, pp. 825-842.

Hillman, A.J, Keim, G.D. and Schuler, D. (2004). "Corporate political activity: A review and research agenda", Journal of Management, Vol. 30, pp. 837-857.

Ingenhoff, D. and Marschlich, S. (2019). "Corporate diplomacy and political CSR: Similarities, differences and theoretical implications", Public Relations Review, Vol. 45, pp. 348-371. 
Joutsenvirta, M. and Vaara, E. (2015). "Legitimacy struggles and political corporative social responsibility in international settings: A comparative discurse analysis of a contested investment in Latin America", Organization Studies, Vol. 36 No. 6, pp. 741777.

Kahneman, D. and Tversky, A. (1984). "Choices, values and frames", American Psychologist, Vol. 39, pp. 341-350.

Kasperson, R.E., Golding, D. and Tuler, S. (1992). "Social distrust as a factor in siting hazardous facilities and communicating risk", Journal of Social Issues, Vol. 48 No. 4, pp. 161-187.

Katsikeas, C.S., Auh, S., Spyropoulou, S. and Menguç, B. (2018). "Unpacking the relationship between sales control and salesperson performance: A regulatory fil perspective", Journal of Marketing, Vol. 82 No. 3, pp. 45-69.

Kelley, H.H. (1967). "Attribution theory in social psychology”, in Levine, D. (Ed.), Nebraska symposiun on motivation, Vol. 15, pp. 192-240, University of Nebraska Press, Lincoln, NE.

Kelley, H.H. (1972). “Attribution in social interaction”, in Jones, E.E., Kanouse, D.E., Kelley, H.H., Nisbett, R.E., Valins, S. and Weiner, B. (Eds.), Attribution: Perceiving the causes of behavior, pp. 1-26, General Learning Press, Morristown, NJ.

Kim, S. and Lee, Y-J. (2012). "The complex attribution process of CSR motives", Public Relations Review, Vol. 38, pp. 168-170.

Kim, H. and Lee, T.H. (2018). "Strategic CSR communication: A moderating role of transparency in trust building", International Journal of Strategic Communication, Vol. 12 No. 2, pp. 107-124. 
Lacey, R. and Kennett-Hensel, P.A. (2010). "Longitudinal effects of corporate social responsibility on customer relationships", Journal of Business Ethics, Vol. 97 No. 4, pp. 581-597.

Lawton, T., McGuire, S. and Rajani, T. (2013). "Corporate political activity: A literature review and research agenda", International Journal of Management Reviews, Vol. 15 No. 1, pp. 86-105.

Liedong, T.A., Ghobadian, A., Rajwani, T. and O'Regan, N. (2015). "Toward a view of complementarity: Trust and policy influence effects of corporate social responsibility and corporate political activity", Group \& Organization Management, Vol. 40 No. 3, pp. $405-427$.

Lock, I. and Seele, P. (2016). "Deliberative lobbying? Toward a noncontradiction of corporate political activities and corporate social responsibility?", Journal of Management Inquiry, Vol. 25 No. 4, pp. 415-430.

López-Navarro, M.A., Llorens-Monzonís, J. and Tortosa-Edo, V. (2013). “The effect of social trust on citizens' health risk perception in the context of a petrochemical industrial complex", International Journal of Environmental Research and Public Health, Vol 10 No. 1, pp. 399-416.

López-Navarro, M.A., Llorens-Monzonís, J. and Tortosa-Edo, V. (2016). "Residents' behaviour as a function of cognitive appraisals and affective responses toward a petrochemical industrial complex", Journal of Cleaner Production, Vol. 112, pp. 16451657.

López-Navarro, M.A., Tortosa-Edo, V. and Castán-Broto, V. (2018). "Firm-local community relationships in polluting industrial agglomerations: How firms' 
commitment determines residents' perceptions", Journal of Cleaner Production, Vol. 186, pp. 22-33.

Luyckx, J. and Janssens, M. (2016). "Discursive legitimation of a contested actor over time: The multinational corporation as a historial case (1964-2012)", Organization Studies, Vol. 37 No. 11, pp. 1595-1619.

Lyon, T.P., Delmas, M.A., Maxwell, J.W., Bansal, P., Chiroleu-Assouline, M., Crifo, P., Durand, R., Gond, J-P., King, A., Lenox, M., Toffel, M., Vogel, D. and Wijen, F. (2018). "CSR needs CPR: Corporate Sustainability and Politics", California Management Review, Vol. 60 No. 4, pp. 5-24.

Mackenzie, S.B. and Podsakoff, P.M. (2012). "Common method bias in marketing: causes, mechanisms, and procedural remedies", Journal of Retailing, Vol. 88 No. 4, pp. $542-555$.

Malhotra, N.K., Kim, S.S. and Patil, A. (2006). "Common method variance in IS research: A comparison of alternative approaches and a reanalisys of past research", Management Science, Vol. 52 No. 12, pp. 1865-1883.

Mantere, S., Pajunen, K. and Lamberg, J-A. (2006). "Vices and virtues of corporate political activity: The challenge of international business", Business \& Society, Vol. 48 No. 1, pp. 105-132.

Marqués, J.C. (2017). "Industry business associations: Self-interested or socially conscious?", Journal of Business Ethics, Vol. 143 No. 4, pp. 733-751.

Mercer-Mapstone, L., Rifkin, W., Louis, W.R. and Moffat, K. (2018). "Companycommunity dialogue builds relationships, fairness, and trust leading to social acceptance 
of Australian minin developments", Journal of Cleaner Production, Vol. 184, pp. 671677.

Meyer, J. and Rowan, B. (1977). "Institutionalized organizations. Formal structure as myth and ceremony", American Journal of Sociology, Vol. 83 No. 2, pp. 340-363.

Moffat, K. and Zhang, A. (2014). "The paths to social licence to operate: An integrative model explaining community acceptance of mining", Resources policy, Vol. 39, pp. 6170.

Nyberg, D., Spicer, A. and Wright, C. (2013). "Incorporating citizens: Corporate political engagement with climate change in Australia", Organization, Vol. 20 No. 3, pp. 433-453.

Oll, J., Hahn, R., Reimsbach, D., \& Kotzian, P. (2018). “Tackling complexity in business and society research: the methodological and thematic potential of factorial surveys", Business \& Society, Vol. 57 No. 1, pp. 26-59.

Owen, J. R., \& Kemp, D. (2013). "Social licence and mining: A critical perspective", Resources Policy, Vol. 38 No. 1, pp. 29-35.

Palazzo, G. and Scherer, A.G. (2008). "Corporate social responsibility, democracy, and the politicization of the corporation", Academy of Management Review, Vol. 33 No.3, pp. 773-775.

Park, J., Lee, H. and Kim, C. (2014). “Corporate social responsibilities, consumer trust and corporate reputation: South Korean consumers' perspectives", Journal of Business Research, Vol. 67 No. 3, pp. 295-302.

Peterson, K. and Pfitzer, M. (2009). "Lobbying for good”, Stanford Social Innovation Review, Vol. 7, pp. 44-49. 
Phillimore, P. and Moffat, S. (2004). "If we have wrong perceptions of our area, we cannot be surprised if others do as well. Representing risk in Teesside's environmental politics", Journal of Risk Research, Vol. 7 No. 2, pp. 171-184.

Podsakoff, P.M. and Organ, D.W. (1986). "Self-reports in organizational research: problems and prospects”, Journal of Management, Vol. 12 No. 4, pp. 531-544.

Podsakoff, P.M., Mackenzie, S.B., Lee, J.-Y. and Podsakoff, N.P. (2003). "Common method bias in behavioral research: A critical review of the literature and recommended remedies", Journal of Applied Psychology, Vol. 88 No. 5, pp. 879-904.

Poortinga, W. and Pidgeon, N.F. (2004). "Trust, the asymmetry principle, and the role of prior beliefs", Risk Analysis, Vol. 24 No. 6, pp. 1475-1486.

Porter, M.E. and Kramer, M.R. (2004). Strategy and society: The link between competitive advantage and corporate social responsibility", Harvard Business Review, Vol. 84 No. 12, pp. 5-12.

Rasche, A. (2015). "The corporation as a political actor - European and North American perspectives”, European Management Journal, Vol. 33 No. 1, pp. 4-8.

Rehbein, K. and Schuler, D.A. (1999). "Testing the firm as a filter of corporate political action”, Business \& Society, Vol. 38 No. 2, pp. 144-167

Rehbein, K. and Schuler, D.A. (2015). "Linking corporate community programs and political strategies: A resource-based view”, Business \& Society, Vol. 54 No. 6, pp. 794821. 
Rousseau, D.M., Stikin, S.B., Burt, R.S. and Carmerer, C. (1998). "Not so different after all: A cross-discipline view of trust", Academy of Management Review, Vol. 23 No. 3, pp. 393-404.

Ruef, M. and Scott, W.R. (1998). "A multidimensional model of organizational legitimacy: Hospital survival in changing institutional environments", Administrative Science Quarterly, Vol. 43 No. 4, pp. 877-904.

Rust, R.T., Zahorik, A.J. and Keiningham, T.L. (1995). "Return on quality (ROQ): Making service quality financially accountable", Journal of Marketing, Vol. 59 No. 2, pp. 58-70.

Scherer, A.G. and Palazzo, G. (2007). "Toward a political conception of corporate responsibility: Business and society seen from a Habermasian perspective", Academy of Management Review, Vol. 32 No. 4, pp. 1096-1120.

Scherer, A.G. and Palazzo, G. (2011). "The new political role of business in a globalized world: A review of a new perspective on CSR and its implications for the firm, governance, and democracy", Journal of Management Studies, Vol. 48 No. 4, pp. 899-931.

Scherer, A.G., Rasche, A., Palazzo, G. and Spicer, A. (2016). "Managing for political corporate social responsibility: New challenges and directions for PCSR 2.0", Journal of Management Studies, Vol. 53 No. 3, pp. 273-298.

Scott, W.R. (1995). Institutions and organizations, Sage, Thousand Oaks, CA.

Scott, W.R. (2008). Institutions and Organizations: Ideas and interests, Sage Publications, London, EN. 
Seidman, G.W. (2007). Beyond the Boycott: Labor Rights, Human Rights, and Transnational Activism, Russell Sage Foundation, New York, NY.

Sen, S. and Bhattacharya, C.B. (2001). "Does doing good always lead to doing better? Consumer reactions to corporate social responsibility". Journal of Marketing Research, Vol. 38 No. 2, pp. 225-243.

Siegrist, M. and Cvetkovich, G. (2001). "Better negative than positive? Evidence of a bias for negative information about possible health dangers", Risk Analysis, Vol. 21 No. 1, pp. 199-206.

Signorino, G. (2012). "Proximity and risk perception. Comparing risk perception "profiles" in two petrochemical areas of Sicily (Augusta and Milazzo)", Journal of Risk Research, Vol. 15 No. 10, pp. 1223-1243.

Slob, B. and Weyzig, F. (2009). "Corporate lobbying and corporate social responsibility: Aligning contradictory agendas", Marques, S.C. and P. Utting (Eds.), Business, Politics and Public Policy, Palgrave Mcmillan, New York, NY.

Slovic, P. (1993). "Perceived risk, trust, and democracy", Risk Analysis, Vol. 13 No. 6, pp. 675-682.

Spanish Institute of Statistics (2011). "Tablas población por municipios", available at: http://www.ine.es/FichasWeb/RegMunicipios.do?fichas=49\&inputBusqueda=\&comuni dades $=9005 \&$ botonFichas $=I r+a+l a+$ tabla + de+resultados, (accessed 1 July 2016).

Ter Huurne, E.F.J. and Gutteling, J.M. (2009). "How to trust? The importance of selfefficacy and social trust in public responses to industrial risks", Journal of Risk Research, Vol. 12 No. 6, pp. 809-824. 
Terwel, B.W., Harinck, F., Ellemers, N. and Daamen, D.D.L. (2009). "How organizational motives and communications affect public trust in organizations: The case of carbon dioxide capture and storage", Journal of Environmental Psychology, Vol. 29, pp. 290-299.

Timonen, L. and Luoma-aho, V. (2010). "Sector-based corporate citizenship", Business Ethics: A European Review, Vol. 19 No. 1, pp. 1-13.

Tortosa-Edo, V., López-Navarro, M.A., Llorens-Monzonís, J. and Rodríguez-Artola, R.M. (2014). "The antecedent role of personal environmental values in the relationships among trust in companies, information processing and risk perception", Journal of Risk Research, Vol. 17 No. 8, pp. 1019-1035.

Tortosa-Edo, V., López-Navarro, M.A. and Llorens-Monzonís, J. (2016). “Antecedent factors of the need for information regarding petrochemical complex hazards", Journal of Risk Research, Vol. 19 No. 2, pp. 135-152.

Tselengidis, A. and Östergren, P.O. (2019). "Lobbying against sugar taxation in the European Union: analysing the lobbying arguments and tactics of stakeholders in the food and drink industries", Scandinavian Journal of Public Health, Vol. 47 No. 5, pp. $565-575$.

Vlachos, P.A., Tsamakos, A., Vrechopoulus, A.P. and Avramidis, P.K. (2009). "Corporate social responsibility: Attributions, loyalty, and the mediating role of trust", Journal of the Academy of Marketing Science, Vol. 37, pp. 170-190.

Vogel, D. (1983). "The power of business in America: A re-appraisal”, British Journal of Political Science, Vol. 13 No. 1, pp. 19-43. 
Warhurst, A. and Mitchell, P. (2000). "Corporate social responsibility and the case of Summitville mine”, Resources Policy, Vol. 26 No. 2, pp. 91-102.

Wöcke, A. and Moodley, T. (2015). "Corporate political strategy and liability of foreignness: Similarities and differences between local and foreing firms in the South African Health Sector", International Business Review, Vol. 24 No. 4, pp. 700-709.

Yoon, Y., Gürhan-Canli, Z. and Schwarz, N. (2006). "The effect of corporate social responsibility (CSR) activities on companies with bad resputations", Journal of Consumer Psychology, Vol. 16 No. 4, pp. 377-390.

Young, S.L. and Makhija, M.V. (2014). "Firms' corporate social responsibility behavior: An integration of institutional and profit maximization approaches", Journal of International Business Studies, Vol. 45 No. 6, pp. 670-698.

Zasuwa, G. (2019). "Do consumers really care about organisational motives behind CSR? The moderating role of trust in the company", Social Responsibility Journal, Vol. 15 No. 8, pp. 977-991. 
TABLE 1

Dimensionality, reliability and convergent validity of the scales of the model

\begin{tabular}{|c|c|c|c|c|}
\hline Items & Mean & Standard Dev. & $\begin{array}{l}\text { Factor Loading } \\
\text { (standarised) }\end{array}$ & $\mathrm{t}$-Test \\
\hline \multicolumn{5}{|c|}{ Public goods perception (political CSR) } \\
\hline $\begin{array}{l}\text { P.1.1 The companies in the } \\
\text { industrial estate invest some of } \\
\text { their profits in improving the } \\
\text { quality of life of the community }{ }^{1}\end{array}$ & 2.37 & 1.229 & 1 & Fixed \\
\hline \multicolumn{5}{|c|}{ Lobbying functions perception (CPA) } \\
\hline $\begin{array}{l}\text { P.2.1 Public authorities are heavily } \\
\text { influenced by the companies in the } \\
\text { industrial estate when evaluating } \\
\text { environmental risks }\end{array}$ & 3.40 & 1.331 & 1 & Fixed \\
\hline \multicolumn{5}{|c|}{ Trust in companies } \\
\hline \multicolumn{5}{|c|}{$\mathrm{AVE}=0,85$, Composite Reliability $=0,97$} \\
\hline $\begin{array}{l}\text { P.3.1 These companies protect } \\
\text { local residents from possible harm } \\
\text { derived from their activities }\end{array}$ & 2.86 & 1.279 & 0.955 & Fixed \\
\hline $\begin{array}{l}\text { P.3.2 I believe these companies } \\
\text { when they say that they do as much } \\
\text { as possible to minimise the risk of } \\
\text { the residents }\end{array}$ & 2.63 & 1.352 & $0.897 *$ & 51.00 \\
\hline $\begin{array}{l}\text { P.3.3 These companies are } \\
\text { concerned about the safety and } \\
\text { health of citizens }\end{array}$ & 2.79 & 1.264 & $0.979 *$ & 77.09 \\
\hline $\begin{array}{l}\text { P.3.4 These companies know how } \\
\text { to handle the risks deriving from } \\
\text { their activities }\end{array}$ & 3.17 & 1.383 & $0.834 *$ & 41.95 \\
\hline $\begin{array}{l}\text { P. } 3.5 \text { these companies listen to and } \\
\text { are sensitive to the environmental } \\
\text { worries of residents }\end{array}$ & 2.73 & 1.293 & $0.949 *$ & 77.36 \\
\hline \multicolumn{5}{|c|}{ Fit of the model: } \\
\hline \multicolumn{5}{|c|}{$\begin{array}{c}\text { Satorra-Bentler chi squared }=57.162 ; \text { d.f. }=11 ; \text {-value }=0.000 ; \text { RMSEA }=0.075 ; \text { CFI }=0.991 ; \text { BBNFI }= \\
0.989\end{array}$} \\
\hline
\end{tabular}

* Significant at $\mathrm{p} \leq 0.001$

${ }^{1}$ To enhance understanding of the item, respondents were given some examples of local firms' investments in public provision to improve citizens' quality of life; specifically, we included the expression "educational services, cultural services, etc" 
TABLE 2

Discriminant validity of the scales

\begin{tabular}{|l|c|c|c|}
\hline \multicolumn{1}{|c|}{ Factors } & $\begin{array}{c}\text { (1) Public goods } \\
\text { perception (political CSR) }\end{array}$ & $\begin{array}{c}\text { (2) Lobbying functions } \\
\text { perception (CPA) }\end{array}$ & (3) Trust in companies \\
\hline $\begin{array}{l}\text { (1) Public goods perception } \\
\text { (political CSR) }\end{array}$ & - & & \\
\hline $\begin{array}{l}\text { (2) Lobbying functions perception } \\
\text { (CPA) }\end{array}$ & $-0.059^{+}$ & - & \\
\hline (3) Trust in companies & $0.321^{*}$ & $-0.364^{*}$ & 0.924 \\
\hline
\end{tabular}

Diagonal: square root of AVE of a latent factor

Below the diagonal: Pearson correlation coefficients between variables

* Significant at $\mathrm{p} \leq 0.05$

+ non significant at $\mathrm{p} \leq 0.05$ 
TABLE 3

Hypotheses corroboration

\begin{tabular}{|c|c|c|c|}
\hline Direct causal effects & $\begin{array}{l}\text { Parameter estimates } \\
\text { (standarised values) }\end{array}$ & S.E & $\mathrm{t}$-Test \\
\hline $\begin{array}{c}\mathrm{H}_{1} \text { : Public goods perception } \rightarrow \text { Trust in } \\
\text { companies }\end{array}$ & $0.302 *$ & 0.038 & 7.91 \\
\hline $\begin{array}{c}\mathrm{H}_{2} \text { : Lobbying functions perception } \rightarrow \text { Trust in } \\
\text { companies }\end{array}$ & $-0.348 *$ & 0.034 & -9.38 \\
\hline $\begin{array}{c}\mathrm{H}_{3} \text { : Lobbying functions perception } \rightarrow \text { Trust in } \\
\text { companies outweighs Public goods perception } \rightarrow \\
\text { Trust in companies }\end{array}$ & \multicolumn{3}{|c|}{$|0.302|<|-0.348|$} \\
\hline Dependent Factor & \multicolumn{3}{|c|}{$\mathrm{R}^{2}$} \\
\hline Trust in companies & \multicolumn{3}{|c|}{0.212} \\
\hline Goodness-of-fit indices for the structural model & \multicolumn{3}{|c|}{$\begin{array}{c}\text { Satorra-Bentler chi square }=60.364 ; \mathrm{df}=12, \\
\mathrm{p} \text {-value }=0.000 ; \text { RMSEA }=0.074 ; \mathrm{CFI}=0.991 ; \\
\text { BBNFI }=0.989\end{array}$} \\
\hline
\end{tabular}

* Significant at $\mathrm{p} \leq 0.05$ 